\title{
The Added-Value Metric - A Complementary Performance Measure for Six Sigma and Lean Production
}

\author{
Djoko Setijono \& Jens J. Dahlgaard \\ Department of Forest and Wood Technology, School of Technology \& Design, \\ Växjö University, Sweden \\ Division of Quality Technology and Management, Linköping University, \\ Sweden
}

djoko.setijono@vxu.se; jenda@ikp.liu.se

\begin{abstract}
The Six Sigma and Lean Production methodologies suggest that creating value for customers is the objective of a production process or an organisation. In the production context, "added value" dominates the discussion about the creation of value to customers. However, "added value" is often only defined conceptually or discussed at a strategic level, and the link between added value and customer value has not yet been well conceptualised. Therefore, the purpose of the paper is to develop a methodology to measure added value in order to complement the existing performance measures in Six Sigma and Lean Production by conceptualising the link between customer value and added value. The conceptual link "confirms" that quality, time, and costs are the elements of added value, which are transformed into a metric to express customer value. The implementation of the metric recommends the adoption of Lean (Six) Sigma and Lean Accounting (Activity Based Costing), which thus implies that "leanness" is an important "feature" of added value.
\end{abstract}

Keywords: Added value, Performance measure, Customer Value, Six Sigma, Lean Production

Category: Conceptual paper

\section{Introduction}

According to Conti (2005), an organization is a system that generates [customer] value. This statement implies that a firm is a value-adding operation (Grönroos, 1996) or system (Fawcett and Fawcett, 1995), where the value added by a firm is the value created by all the players in the vertical chain minus the value created by all the players except the one in question (Branderburger and Stuart, 1996; in de Chernatony et al, 2000). Moreover, the Six Sigma and Lean Production methodologies suggest that the objective of a production process is to create, deliver, and improve customer value (Womack \& Jones, 1996; Breyfogle, 2001; Liker, 2004). Thus, added value becomes a company's attempt to provide value for its customers. Hence, in the production context, customer value is "acknowledged" as added value under a circumstance that in different contexts, customer value may "appear" in different "modes" (Setijono, 2005).

The hypothetical relationship or association between added value and customer value has been described by, e.g. de Chernatony et al (2000) and Grönroos (1997), besides that the relationship seems to be well grounded within the principles of Lean Production. According to de Chernatony et al (2000), added value enables 
organizations to deliver superior customer value as well as enables customers to recognize superior value and be more confident in their choice. The term "customer value" stated by de Chernatony (2000) refers to the value recognised by customers prior to the purchase or acquisition of a product, i.e. perceived customer value. The hypothetical relationship between added value and customer value suggested by de Chernatony (2000) seems to be consistent with the way Grönroos (1997) defines the relation between [perceived] customer value and added value, that Perceived Customer Value $=$ Core Value \pm Added Value. This relation implies that added value may have a positive or negative impact on perceived customer value.

Gale (1994) suggests that perceived customer value is the ratio between market perceived quality and market perceived price. Meanwhile, Harry \& Crawford (2005) defines added value as a function of utility, access, and costs. Although Grönroos (1997) and Gale (1994) discuss the same concept, their descriptions and/or formulations indicate a divergence. Therefore, comparing these two definitions might be confusing. A possible explanation is that Gale (1994) explains perceived customer value from the purchaser's (customer's) point of view, while Grönroos (1997) explains a similar concept from the view of a service provider (producer).

The five principles of Lean Production [i.e. defining customer value, identifying the value stream, making the value creation steps flow, let the customers pull the value from the value stream, and pursue perfection in creating value] (see e.g. Womack and Jones, 1996; Liker, 2004; Dahlgaard and Dahlgaard Park, 2006) contain the philosophy that the way a company creates value to its customers will influence the customers' perception about value. The main "message" behind the five principles of Lean Production is that the producer first interprets (define) customer value into several specific criteria. These criteria determine the value stream, where the "value" flows along the defined stream, so that the cus tomers can pull the value from the producer at the time they wish. The way of expressing value also needs to be continuously improved towards perfection.

Hence, we notice that: 1) the hypothetical relationship or association between added value and customer value is somewhat fuzzy, in the sense that there is no adequate conceptualisation provided, although the relationship between added value and customer value exists theoretically and is acknowledged by researchers, and 2) this fuzziness might be the reason behind the "absence" of performance measures which adequately reflect the notion of customer value. This is probably why the performance measures in Six Sigma and Lean Production inadequately indicate the success (eventually failure) of a company in providing and/or improving customer value.

Therefore, the purpose of this paper is to explain the conceptual link between added value and customer value in order to understand in what way added value enhances customer value, so that the suggested methodology to measure added value may be used to indicate the customer value creation.

The paper will be organized in the following way: first, the authors will provide a theoretical review about customer value and performance measures in Six Sigma and Lean Production. Then, a conceptual link between added value and customer value will be described. Next, the authors suggest a methodology to use the added value as a metric to measure performance. The paper finalizes with conclusions. 


\section{Literature review}

\section{Performance measures in Six Sigma and Lean Production}

According to Breyfogle et al (2001), the metrics used to measure performance must be related to customer value. However the existing Six Sigma metric, i.e. number of defect per million opportunities (dpmo) does nt seem to reflect the customer-value orientation because: 1) quality, as an important component of customer value is not merely about defects and it is not adequate to measure quality based on just defects, 2) customer value as a metric, is a function of carefully selected cost elements, and the dpmo in itself "fails" to show or express this relation in its metric.

The weaknesses of the dpmo metrics become more obvious if we consider the statement of George (2002) that the dpmo is not always applicable at a corporate level or in service-oriented companies due to the fact that it is not always easy to define and count defects. George (2002) further states that many Six Sigma practitioners have not yet addressed the issue of the importance of non-manufacturing defects related to dpmo or their value.

A similar phenomenon can also be found in Lean Production, where the performance measure does not well reflect the intended goal to be achieved. The main goal of Lean Production is to provide customer value (Womack and Jones, 1996; Hines et al, 2004), but the application of lean thinking at the operational level, i.e. in terms of shop-floor tools, does not apply this principle (Hines et al, 2004). The "success" in providing customer value is measured through cycle time, under the assumption that the reduction or elimination of waste will create a smoother flow and a shorter cycle time. Time is certainly an important element of customer value, but measuring customer value merely in terms of cycle time is considered to be inadequate.

\section{Customer value in the context of production}

There is a "universal agreement" that value is a means to gain competitive advantage (Grönroos, 1997; de Chernatony, 2000; Huber et al, 2001; Khalifa, 2004) besides its extensive application in various disciplines (Wikstrom and Normann, 1994; in Huber et al, 2001). Although it is "agreed" that customer value is generally defined as a ratio between benefits and sacrifices (see e.g. Gale, 1994; Ravald and Grönroos, 1996; Dumond, 2002; Khalifa, 2004), value is a complex and difficult-to-define term (de Chernatony et al, 2000; Khalifa, 2004) because "... the value concept is multifaceted and complicated by numerous interpretations, biases, and emphases" (Huber et al, 2001; pp. 42).

Setijono (2005) suggests that, in the context of production, customer value manifests into added value. Added value becomes the cues to recognize superior customer value that may lead to confidence in choice (de Chernatony et al, 2000). Hence, it may imply that added value is a "trade mark", which "certifies" that the product is valuable for customers in the sense that customers "get" more than what they "give" (i.e. the benefits is higher than the sacrifices). Harry \& Crawford (2005) provide a conceptual formulation of added value (AV), that:

$$
A V=\frac{U^{*} A}{C}
$$


Where $U$ is the utility, A represents access, and the cost is defined as C. Equation (1) implies that the added value to customers is reduced if the product is not easily accessed when needed (A $<100 \%)$ and/or if the product is too costly, although the product has "perfect" utility $(\mathrm{U}=100 \%)$.

\section{Linking added value and perceived customer value}

First-order and second-order models of perceived customer value

Defining perceived customer value, as a ratio between "overall benefits" (such as market perceived quality) and "overall sacrifices" (such as market perceived price) represents a second-order model of perceived customer value. Thus the relation between "benefits" and "sacrifices" with the construct of perceived customer value is formative, which means that the "benefits" and "sacrifices" are the components of perceived customer value or have a causal effect on it (Lin et al, 2005). It is likely that we could select several variables to describe what "benefits" and "sacrifices" consist of when we "break down" or "disaggregate" the "benefits" and "sacrifices". The result leads to a first-order model of perceived customer value, where the "benefits" consist of "get 1", "get 2", ... "get n" (variables that are related/associated to the benefits gained by the customers) and the "sacrifices" consist of "give 1", "give 2", ... "give n" (variables that are related/associated to the sacrifices that the customers need to make when obtaining the product). Unlike the second-order model, the first-order model is reflective, which means that those selected variables are the manifestation or the effect of perceived customer value (Lin et al, 2005).

Figure 1 describes the first-order and the second order models of customer perceived value. The figure is adapted from Lin et al (2005) with modifications

\section{$<$ Take in figure 1>}

Figure 1. The conceptualisation of perceived customer value

Lapierre (2000) uses first-order dimensions (where each dimension consists of several variables) such as product quality, responsiveness, reliability, price, timeleffort/energy, etc and classifies these dimensions into the following categories: product-related, service-related, and relationship related. Lin et al (2005) use "constructs" (where each construct also consist of several variables) such as monetary sacrifice, fulfilment/reliability, customer service, (the efficiency of) website design, etc. With this background, we classified the first-order dimensions as described in Lapierre (2000) and the constructs as described by Lin et al (2005) into the following categories: quality (of product, services, and relationship), time, and price. The "new" way of categorizing the first-order dimensions (constructs) becomes the key to understand the link between added value and customer value.

\section{Convergence meanings/interpretations of added value}

Viewing the first-order variables of perceived customer value from a different angle leads to an understanding that quality, costs, and price are important manifestations (or indicators) of customer [perceived] value. This finding is consistent with the statement of Womack and Jones (1996, pp. 141) regarding customer value that it should be "...defined in terms of a specific product with specific capabilities offered at a specific time and price". Kippenberger (1997) discussed that a product with specific capabilities offered at a specific time and price is a meaningful expression of 
customer value. Thus, the product's capabilities, time, and price are producer's view regarding what customer value comprises.

According to Harry and Crawford (2005), added value can be defined as a function of utility, access and costs. Harry and Crawford describe utility as the form, fit, and function of the product", and access as "factors such as the volume produced, the timing of availability to the market, and the location of distribution" (ibid, pp. 130). It is the clear that utility refers to quality, while access is related to time.

Considering that 1) product capabilities are the basis for customers to judge product quality, and 2) price is a sum of costs and margin, then the definitions of value suggested by Harry and Crawford (2005) and Womack and Jones (1996) reached a consistency (convergence) in meaning or interpretation. Thus we conclude that added value is the manifestation of customer value in a production context, which comprises quality, time, and costs.

Hence, it is suggested that added value (AV) is defined as:

$$
A V=\frac{Q^{*} T}{C}
$$

From (2), it follows that the condition for improved added value is that at least one of the following requirements is fulfilled: improved quality $(\mathrm{Q})$, improved time $(\mathrm{T})$, and reduced cost $(\mathrm{C})$. This formula is useful as the basis to develop a metric to measure added value in relation to customers.

\section{Conceptualization of the link between added value and customer value}

The description from the previous section has "revealed" the "invisible" link between added value and customer value, and it has been described that the basic "ingredients" of added value are quality, time, and costs. However, the complexity of conceptualising the link between added value and perceived customer value may stem from the fact that: 1) it involves two entities and two different contexts, where supplier (producer) and customers may have different interpretations of quality, time, and costs, and 2) it may be risky if the interpretation and the expression of value doesn't "match". Incorrect interpretation and expression may lead to a failure in recognizing superior customer value, and thus the "absence" of a purchase transaction. Therefore, conceptualising the link between added value and customer value is a "delicate" matter and requires careful reflections. The following description conceptualises the link between added value and cus tomer value.

The customers prefer to buy a product or service, which is capable to fulfil their needs and/or goals. Thus, customers judge product or service quality based on the capability to fulfil their goals or needs. However, the producer (supplier) interprets quality as: 1) the attractiveness of the product to the customers and 2) the product should be free from defects. Through these interpretations, the producer may expect that the product will likely satisfy customers' needs and intended goals.

Customers' view regarding time is that the product or service should be available when needed or just-in-time (Womack and Jones, 2005). However, the producer interprets just in time (JIT) as a shorter and shorter cycle time. Even though shorter 
cycle time is a "misconception" of the actual JIT meaning, it enables the producer to ensure that product or service is available when it is needed.

The customers prefer that the price should be fair (Padula and Bussaca, 2005). When the price is fair, it might also be perceived as cheap. The perception of fairness or cheapness is a result of comparison between the customer willingness to pay and the actual price offered by the producer, and thus it may not always be associated with a lower price. However, the producer interprets fair or cheap as a continuous reduction of product cost. Even though a continuous reduction of product cost may not be a "correct" interpretation of fair or cheap, it enables the producer to ensure that the price offered would not exceed the price level that the customers are willing to pay.

Figure 2 provides a [visual] conceptualisation of the link between added value and perceived customer value, as well as explains how added value becomes the enabler of customer value. The figure may enable companies to develop a methodology to measure added value.

\section{$<$ Take in figure 2>}

Figure 2. Added value as the enabler of customer value

\section{Measuring added value}

According to Anderson \& Narus (2004), customer value consists of the following elements: product leadership, customer intimacy, and operational excellence. De Chernatony et al (2000) stated that "focus on process" is an important character of added value, and it is the property that makes added value an enabler of customer value. This implies that added value should be measured in the core processes (or value streams).

Six Sigma and Lean Production are process-oriented methodologies that may help companies to achieve product leadership, customer intimacy, and operational excellence. Six Sigma is output-oriented, which explains why dpmo is the most important measure in Six Sigma. Meanwhile, Lean Production is activity-oriented, which explains why faster flow (shorter cycle time) is the most important measure in Lean production. Therefore, the synergy (fusion) between Lean Production and Six Sigma may increase and optimise added value (Arnheiter and Maleyeff, 2005).

These two methodologies have also different views regarding cost and costing. In Six Sigma, the costs are likely determined in a traditional way (product-based). Lean Production, on the other hand, views that costs occur due to a consumption of resources in certain process activities, and thus, it is activity-based (Bhasin and Burcher, 2006). This might explain why Six Sigma emphasizes defect reduction in order to reduce costs, while Lean Production emphasizes smoothing the process flow by reducing or eliminating non-value added activities in order to reduce costs.

Therefore, the implementation of Lean Sigma needs to consider a costing method that reflects customer orientation. Activity Based Costing (ABC) may fulfil this requirement because it is based on the assumption that costs are driven by resource consumption in the processes or activities to give what customers want and value (Lebas, 1995). The application of ABC may support the identification of activities that add and do not add value to customers, which allows a company to identify 
improvement opportunities to reduce or avoid "waste". This might be the reason that $\mathrm{ABC}$ is also known as Lean Accounting (Schonberger, 2005; Bhasin and Burcher, 2006).

Consequently, the application of $\mathrm{ABC}$ is a way to identify non-value added costs (or the quality costs) that takes into account the view of Lean Production regarding costs and costing. Tsai (1998) describes that cost of quality can be identified and measured by using Activity Based Costing (ABC), where the cost of quality is defined as the sum of value-added quality costs and non-value added quality costs. Here, value added quality costs include the costs for preventing failures, while non value-added quality costs are costs of appraisal and costs due to failures (internal and external failures).

The Lean Production (Toyota Production System) methodology defines added value as the actual transformation process or the core process that the customer is paying for, and everything that is not a part of the core process actually does not add value to the customers and will therefore be regarded as "waste" (Liker, 2004). The waste or non-value added could further be classified into necessary waste (e.g. inspections, control systems to check that procedures are being followed, documentation) and pure waste (e.g. failures, reworks). An example from a Danish company (see Dahlgaard and Dahlgaard Park, 2006) showed that a large portion of salary costs for running a service process were spent on waste of different kind. Between $40-50 \%$ of the paid working time was used to identify and correct failures, and the same percentage was used to produce non- value added output.

The two concepts of added value overlap each other and they actually fit perfectly if we see them from the right angle. These two concepts are actually explaining similar things from different perspectives.

The non-value added output or activities (i.e. the wastes) add extra costs $(\Delta \mathrm{C})$ to the "ideal product cost", defined as the costs when "quality is perfect" or there is no waste. This means that $\Delta \mathrm{C}$ is the difference between actual product costs $(\mathrm{C})$ and the product costs when quality is perfect $\left(\mathrm{C}^{*}\right)$. Campanella (1990; in Dahlgaard et al, 1998) defines this as the cost of quality (COQ). Hence we may express that:

$$
C O Q=\Delta C=C-C^{*}
$$

It may then be obvious that the costs of quality are actually non-value added costs. It should also be recognised that a certain cost category in quality costs (i.e. prevention costs) is valuable for the producer to generate (create) what is valuable for the customers.

To sum up, the costs of quality should represent (reflect) both necessary and pure waste, where the costs are measured according to a process-based or activity-based model. The seven types/criteria of waste (Liker, 2004) provide guidelines to determine whether an activity adds value or not.

\section{Customer value as a metric for improvement measurement}

There are two complementary strategies to improve customer value. The first strategy is to focus on product development, where "customer voices" and new understandings 
of customers' latent needs become the input. The second strategy is by focusing on process improvements, where elimination of waste along the value stream is the key. In the second strategy, waste is defined as anything that does not add value to customers, such as failures and other non-value adding activities or output. The improvement efforts to increase the added value should then be focused in either improving the benefits (1st strategy) or reducing unnecessary costs (2nd strategy).

In order to be able to use value added as an operational metric to measure the progress of improvement, we need to ensure that the components of added value have the same unit of measurements. Therefore, the added value to customer (AV) as a metric to measure performance is defined as:

$$
A V=\frac{Q_{r} * T_{r}}{C_{r}}
$$

Thus, added value is a function of the relative performance of quality $\left(Q_{r}\right)$, the relative performance of time $\left(T_{r}\right)$, and the relative performance of $\operatorname{cost}\left(C_{r}\right)$.

Relative performance of quality $\left(Q_{r}\right)$ can be defined as the ratio between the yield (Y) at period (i+1) and yield at period (i). Yield is defined as the percentage of output that conforms to the specifications, i.e. the ratio between the amount of acceptable products and the total amount produced. Then:

$$
Q_{r}=\frac{Y_{i+1}}{Y_{i}}
$$

The waste does not only influence costs, but also cause a longer cycle time than necessary, due to the time consumed by non-value added activities. Therefore, the cycle time $\left(\mathrm{T}_{\mathrm{C}}\right)$ can be generally expressed as a sum between value-added time $\left(\mathrm{T}_{\mathrm{VA}}\right)$ and non-value added time $\left(T_{\overline{V A}}\right)$. A more effective and efficient operation is expected to reduce the non-value added time, and therefore reduce the cycle time. Hence:

$$
T_{C}=T_{V A}+T_{\overline{V A}}
$$

From (6), we define the fraction of value added time ( $v)$, which is defined as a ratio between value-added time $\left(\mathrm{T}_{\mathrm{VA}}\right)$ and the cycle time $\left(\mathrm{T}_{\mathrm{C}}\right)$. Hence:

$$
\mathrm{v}=\frac{T_{V A}}{T_{C}}
$$

Relative performance of time $\left(T_{r}\right)$ is defined as a ratio between the fraction of valueadded time $(v)$ at period $(\mathrm{i}+1)$ and the fraction of value added time at period (i). Then:

$$
T_{r}=\frac{\mathrm{v}_{i+1}}{\mathrm{v}_{i}}
$$


Therefore:

$$
T_{r}=\frac{T_{V A(i+1)} / T_{C(i+1)}}{T_{V A(i)} / T_{C(i)}}=\frac{T_{V A(i+1)}}{T_{V A(i)}} * \frac{T_{C(i)}}{T_{C(i+1)}}
$$

The relative performance of cost $\left(C_{r}\right)$ is defined as the ratio between non-value added $\operatorname{costs}\left(C_{\overline{V A}}\right)$ at period $(\mathrm{i}+1)$ and non- value added costs at period (i). Then:

$$
C_{r}=\frac{C_{\overline{V A}(i+1)}}{C_{\overline{V A}(i)}}=\frac{C O Q_{i+1}}{C O Q_{i}}
$$

The analytical model of added value is consistent with the fundamental definition of customer value (i.e. a ratio between "benefits" and "sacrifice"). In fact, added value becomes the producer's way to express customer value, where reduced number of defects and faster cycle time increase the customers' perception regarding the benefits and reduction of non-value added costs is producer's attempt to reduce customers' sacrifice in getting the benefits. The producer's way of expressing and improving customer value towards sustainable customer value through the entire product's life cycle requires the adaption of Lean Sigma and Lean Accounting, which then implies that "leanness" is a crucial "feature" of added value.

Example:

Let's consider the data as shown by table I in order to calculate the added value.

Table I. Illustrative data

\begin{tabular}{lcc}
\hline & Period (i) & Period (i+1) \\
\hline Yield (\%) & 0.85 & 0.90 \\
Value added time (min) & 105 & 103 \\
Cycle time (min) & 135 & 130 \\
Cost of quality (SEK) & 20,000 & 18,500 \\
\hline
\end{tabular}

Thus, added value is:

$$
A V=\frac{\frac{0.90}{0.85} *\left(\frac{103}{105} * \frac{135}{130}\right)}{\frac{18,500}{20,000}}=1.166
$$

Based on the result, we may interpret that during period (i+1) the company has improved its performance and added $16.6 \%$ more value to the customers.

\section{Conclusions}

Customer value is the "ultimate" goal of Six Sigma, Lean Production, and Lean Sigma methodologies. However, the existing ways of measuring performance hardly indicate (represent) the concept of customer value itself, which might be caused by a "fuzzy" conceptualisation of the link between the value to customers from customers' 
perspective (i.e. customer value) and the value to customers from producer's perspective (i.e. added value). Therefore, in order to overcome this inconsistency, it is necessary to clarify the conceptual link between customer value and added value, which allows us to express added value as a performance measure. The utilization of customer value as a metric is expected to provide a "better" performance measure for both Six Sigma and Lean Production methodologies.

\section{REFERENCES}

Anderson, J.C., Narus, J.A. (2004), Business Market Management-understanding, creating, and delivering value, Second edition, Pearson Prentice Hall, New Jersey.

Arnheiter, E.D., Maleyeff, J. (2005), The Integration of Lean Management and Six Sigma, The TQM Magazine, Vol. 17, No. 1, pp. 5-18.

Bhasin, S., Burcher, P. (2006), Lean viewed as a Philosophy, Journal of Manufacturing Technology Management, Vol. 17, No. 1, pp. 56-72

Breyfogle, F.W., Cupello, J.M., Meadows, B. (2001), Managing Six Sigma: a practical guide to understanding, assessing, and implementing the strategy that yields bottom-line success, John Wiley \& Sons, Inc.

Conti, T. (2005), Quality and Value: convergence of system thinking, Proceeding of World Conference on Quality and Improvement, Seattle.

Dahlgaard, J.J., Kristensen, K., Kanji, G.K. (1998, 2002), Fundamentals of Total Quality Management, Nelson Thornes, UK.

Dahlgaard, J.J., Dahlgaard-Park, S.M. (2006), "Lean Production, Six Sigma Quality, TQM, and Company Culture", TQM Magazine, Vol. 18, No. 3, pp. 263-281.

De Chernatony, L., Harris, F., Riley, F.D. (2000), Added value: its nature, roles, and sustainability, European Journal of Marketing, Vol. 34, No. 1/2, pp. 39-56.

Dumond, E.J. (2000), Value Management: an underlying framework, International Journal of Operations \& Production Management, Vol. 20, No. 9, pp. 1062-1077

Fawcett, S.A., Fawcett, S. A. (1995), The firm as a value-added system, The International Journal of Physical Distribution and Logistics Management, Vol. 25, No. 5, pp. 24-43.

Gale, B.T. (1994), Managing Customer Value, The Free Press, New York.

George, M.L. (2002), Lean Six Sigma - combining Six Sigma quality with Lean speed, McGraw-Hill.

Grönroos, C. (1996), Relationship Marketing: Strategic and Tactical Implication, Journal of Management Decision, Vol. 34, No. 3, pp. 5-14.

Grönroos, C. (1997), Value-Driven Relational Marketing: from Products to Resources and Competencies, Journal of Marketing Management, Vol. 13, No. 5, pp. 407419.

Harry, M., Crawford, D. (2005), "Six Sigma - the next generation", Machine Design, Vol. 77, No. 4, pp. 126-132.

Hines, P., Holweg, M., Rich, N. (2004), "Learning to evolve - a review of contemporary lean thinking", International Journal of Operations \& Production Management, Vol. 24, No. 10, pp. 994-1011.

Huber, F., Hermann, A., Morgan, R.E. (2001), Gaining Competitive Advantage through Customer Value Oriented Management, Journal of Consumer Marketing, Vol. 18, No. 1, pp. 41-53.

Khalifa, A. S. (2004), Customer value: a review of recent literature and an integrative configuration, Journal of Management Decision, Vol. 42, No. 5, pp. 645-666

Kippenberger, T. (1997), Apply Lean Thinking to a Value Stream to Create Lean Enterprise, The Antidote, Vol. 2, No. 5, pp. 11-14. 
Lapierre, J. (2000), Customer Perceived Value in Industrial Context, Journal of Business and Industrial Marketing, Vol. 15, No 2/3, pp. 122-140.

Lebas, M.J. (1995), Performance Measurement and Performance Management, International Journal of Production Economics, Vol. 41, No. 1-3, pp. 23-35.

Liker, J. K. (2004), The Toyota Way, McGraw-Hill.

Lin, C.H., Sher, P.J., Shih, H.Y. (2005), Past Progress and Future Directions in Conceptualizing Customer Perceived Value, International Journal of Service Industry Management, Vol. 16, No. 4, pp. 318-336

Padula, G., Busacca, B. (2005), "The asymmetric impact of price-attribute performance on overall price evaluation", International Journal of Service Industry Management, Vol. 16, No. 1, pp. 28-54.

Ravald, A., Grönroos, C. (1996), The Value Concept and Relationship Marketing, European Journal of Marketing, Vol. 30, No. 2, pp. 19-30.

Schonberger, R.J. (2005), Lean Extended, Industrial Engineer, Vol. 37, No. 12, pp. 26-32.

Setijono, D. (2005), "Customer value measures: indicators and driving factors of quality improvement opportunities and competitiveness", Proceeding of the 8th QMOD Conference, Palermo, Italy.

Tsai, W-H. (1998), "Quality cost measurement under activity-based costing", International Journal of Quality \& Reliability Management, Vol. 15, No. 7, pp. 719-752.

Womack, J.P., Jones, D.T. (1996), "Beyond Toyota: how to root out waste and pursue perfection", Harvard Business Review, Vol. 74, No. 5, pp. 140-152.

Womack, J.P., Jones, D.T. (2005), Lean Solutions: how companies and customers can create value and wealth together, Simon and Schuster, London. 


\section{LIST OF FIGURES}

Figure 1

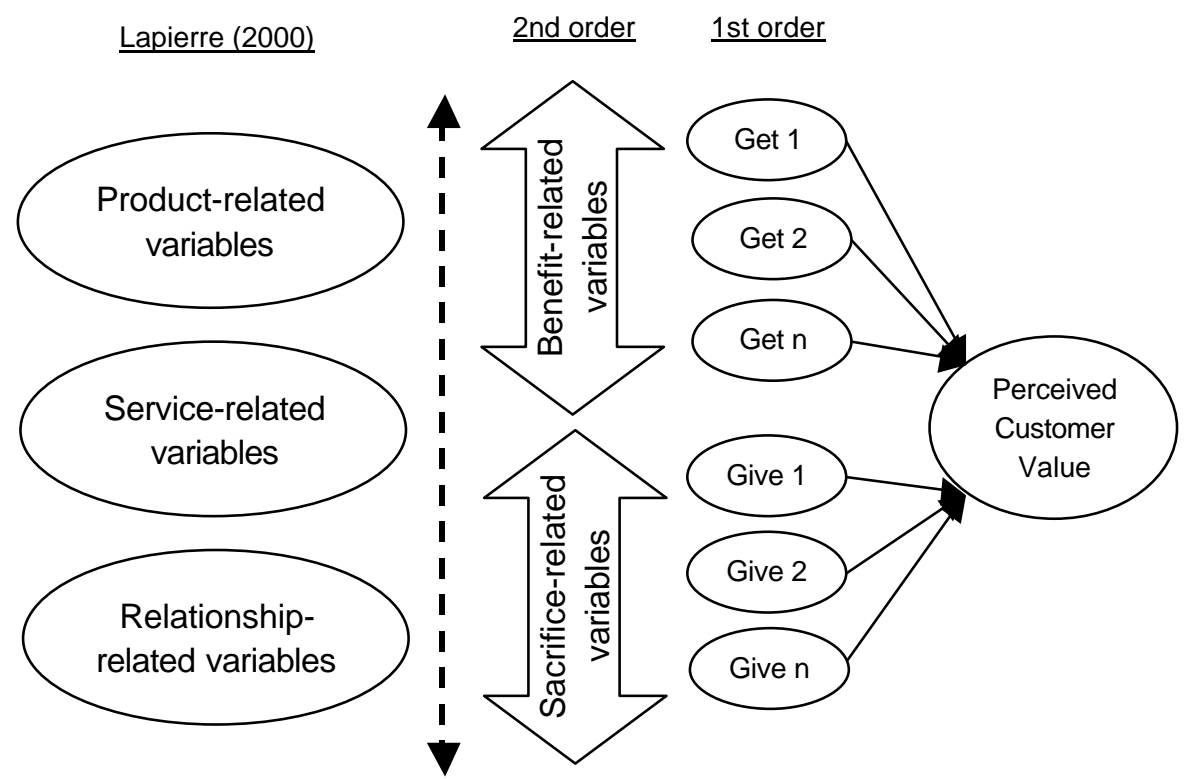


Figure 2

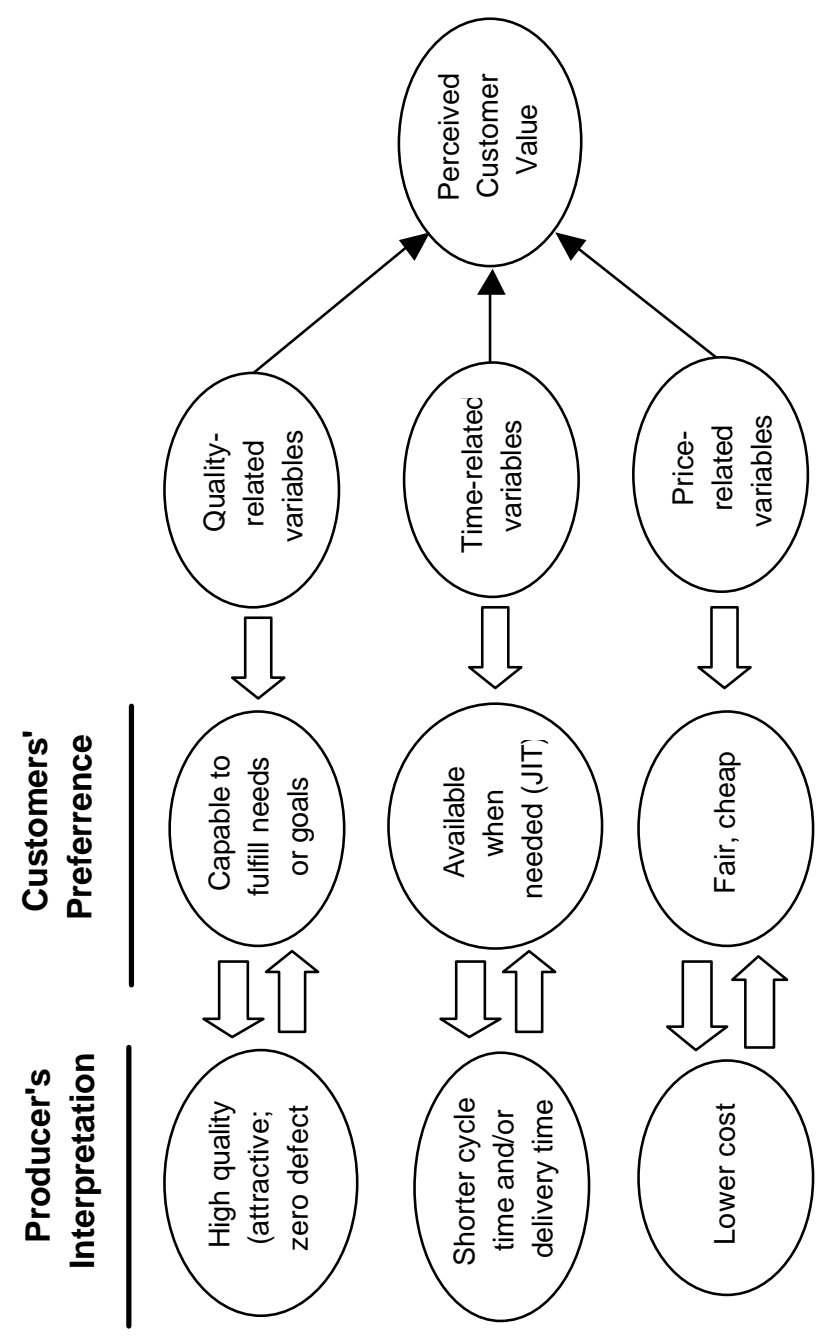

